\title{
The genital and anal papillae of Compsura heterura (Characidae: Cheirodontinae): morphological structure and possible role in a insemination
}

Correspondence: Antônio Queiroz Lezama anlezama@yahoo.com.br

Submitted August 12, 2020

Accepted October 27, 2020 by Elizete Rizzo Epub 08 March, 2021

\author{
${ }^{\circledR}$ Antônio Queiroz Lezama ${ }^{1}$ and ${ }^{\circledR}$ Luiz R. Malabarba ${ }^{1}$
}

The function of the genital and anal papillae for insemination in Compsura heterura is discussed based on the description of their morphologies at different stages of the life cycle and during copulation and spawning. In males and females both the genital and anal papillae are involved in copulation in C. heterura. A pre-anal organ, anterior to the anus and stretched posteriorly, is present in adult males. The openings of the urinary channel and oviduct are separate in females. During copulation, there is an approximation between the female genital and anal papillae which become temporarily juxtaposed, forming a chamber enclosing the opening of the oviduct, which may also function in sperm capture. During spawning, the lateral edges of the female genital papilla are projected anteriorly, acquiring a tubular shape for oviposition.

Keywords: Compsurini, Copula, Pre-anal organ, Sexual dimorphism, Spawning.
Online version ISSN 1982-0224 Print version ISSN 1679-6225

Neotrop. Ichthyol. vol. 19, no. 1, Maringá 2021
1 Programa de Pós-Graduação em Biologia Animal, Departamento de Zoologia, Universidade Federal do Rio Grande do Sul, Av. (LRM) malabarb@ufrgs.br. 
A função das papilas genital e anal na inseminação em Compsura heterura é discutida com base na descrição de suas morfologias em diferentes estágios do ciclo de vida e por ocasião da cópula e desova. Em machos e fêmeas, as papilas genital e anal estão envolvidas na cópula. Um órgão pré-anal, anterior ao ânus e alongado posteriormente, está presente em machos adultos. Fêmeas possuem aberturas urinária e genital separadas. Durante a cópula, ocorre uma aproximação entre as papilas genital e anal femininas, que se justapõem temporariamente, formando uma câmara fechada onde se abre o oviduto, e que serve possivelmente à captura de esperma. Durante a desova, as bordas laterais da papila genital feminina são projetadas anteriormente, adquirindo um formato tubular para ovoposição.

Palavras-chave: Compsurini, Cópula, Desova, Dimorfismo sexual, Órgão préanal.

\section{INTRODUCTION}

Most teleosts (approximately 97\%) are externally fertilizing fishes, in which males and females release gametes in the water where fertilization occurs (Pecio et al., 2007). However, some have been shown to be capable of insemination, in which males are able to transfer sperm to the female reproductive tract (Burns et al., 1997); this may or may not result in internal fertilization. Internal fertilization is known so far in 15 families of the Cohort Euteleosteomorpha and one family of the Cohort Otomorpha (Fukakusa et al., 2020). Within Otomorpha, only the characid fish Compsura heterura Eigenmann, 1915 has been described as internally fertilized, in which females spawn eggs in the zygotic stage (Fukakusa et al., 2020). In other Otomorpha belonging to the order Siluriformes (families Auchenipteridae, Astroblepidae, and Scoloplacidae) and Characiformes (family Characidae), the presence of sperm has been verified within the female reproductive tract but no fertilized eggs or early embryos have been reported, thus the term insemination has been used to characterize the strategy adopted by these fishes (Javonillo et al., 2009). In these cases, the precise moment that fertilization takes place is still unknown. Fertilization may occur via internal gametic association in which spermatozoa associate with the micropyles of the oocytes, but oocytes are only fertilized when released into the water which apparently stimulates fertilization, as exemplified in Cotiidae (Munehara et al., 1989). Fertilization may also take place very rapidly just prior to oviposition inside female reproductive tracts as ovulated eggs enter the lumen of the ovary where spermatozoa are stored, as demonstrated for the characid fish C. heterura (Fukakusa et al., 2020), but confirmation of fertilization in these cases require euthanasia of females at precisely the time of ovulation, something which has yet to be successfully accomplished for most characid species that show spermatozoa stored in ovaries (Javonillo et al., 2009).

Within the orderCharaciformes, insemination is present in subfamilies Cheirodontinae, Stevardiinae, and Stethaprioninae, all belonging to the family Characidae (Javonillo et al., 2009). The presence of intromittent organs that facilitate insemination has been described for some species of the stevardiine genus Monotocheirodon Eigenmann \& 
Pearson, 1924. These organs are essentially elongate urogenital papillae, with associated circular and longitudinal skeletal muscle at the base, suggesting a relative degree of voluntary control over the movement of this structure (Burns, Weitzman, 2006). A urogenital papilla modified into a copulatory organ has also been described for the genus Phallobrycon Menezes, Ferreira \& Netto-Ferreira, 2009 (Menezes et al., 2009). This type of structure, however, is absent in other inseminating characid species and the precise method of sperm transfer remains unknown in these fishes. Other character presumably associated to insemination is observed in the species of the stethaprionine genera Hollandichthys Eigenmann, 1910 and Rachoviscus Myers, 1926, that have the anus and urogenital openings in males and females housed in a body cavity between the pelvic and anal fins in males and females, and that may play some role in the sperm transference from males to females (Bertaco, Malabarba, 2013).

In most inseminating stevardiines, males have several secondary sexual characters, such as modified scales, hooks, spines, and hypertrophied glandular tissues associated with caudal- or anal-fin rays. It was suggested that, in these species, the genital papilla and anal fin may be used for insemination, with the anal fin forming a cavity that directs sperm packets (Kutaygil, 1959; Meisner, 2005). Some representatives of Stevardiinae also have glandular tissue associated with modified scales of the caudal peduncle in mature males, which is considered to be a sex pheromone pump (Weitzman, Menezes, 1998; Weitzman et al., 2005). Within Cheirodontinae, the Compsurini tribe includes all species that have insemination (Malabarba, 1998). Compsurini members also have specialized organs on the male caudal fin, ranging from modified scales to hypertrophied tissue with apparent glandular function (Malabarba, Weitzman, 1999). The species of this tribe also have hypertrophied genital papillae (Jerep, 2011). It was suggested that the male and/or female genital papillae may facilitate sperm transfer during insemination. It is, however, necessary to carry out more detailed studies, both descriptive and experimental, to test this hypothesis.

In the present study, the structure and function of the genital papilla in C. heterura is investigated, describing the macroscopic and microscopic structure of the genital papilla and the morphological changes of the genital papilla at different stages of the life cycle. We found that the anal papilla, also described in this paper, is sexually dimorphic. Hypotheses about the possible mechanism of sperm transfer during copulation are presented based on these observations.

\section{MATERIAL AND METHODS}

Data sampling. Morphological observations of the genital papilla were performed with stereo microscope, light microscope and scanning electron microscope (SEM). Observations of the genital papilla were performed both in juveniles and adults. The genital papilla from adults was observed in: 1) males and females prior to copulation, 2) males and females immediately after copulation and 3) females during spawning. Pictures were taken using photographic equipment Nikon CoolPix 4500. Copulation was observed directly in aquarium specimens. Observations of adults before copulation were performed with virgin specimens, isolated in aquaria at the juvenile stage. In juveniles (standard length [SL] less than $20 \mathrm{~mm}$ ), sexing was performed using histological sections. 
During observations with a stereo microscope, preserved specimens were constantly moistened with $70 \%$ alcohol to prevent drying out and consequent deformation of the genital papilla. Toluidine blue dye was used in order to increase the visual contrast of the morphological structures present in the genital papilla. Living aquarium observations: specimens of Compsura heterura from UFRGS Ichthyology Laboratory from the Maxaranguape stream (0530'45.00”S 35¹9'13.97”W), Maxaranguape city, Rio Grande do Norte State, Brazil. Institutional acronyms follow Sabaj (2019).

Light Microscopy. For histological section, specimens were anesthetized in concentrated solution of eugenol, and fixed in Karnovsky solution (Karnovsky, 1965) for a minimum of $72 \mathrm{~h}$. After fixation, the material was stored in $70 \%$ alcohol for a minimum time of $24 \mathrm{~h}$, then dehydrated in alcohol solutions of $90 \%, 95 \%$ and $100 \%$, and impregnated in historesin, following Gerrits, Horobin (1991). Historesin blocks containing tissues were cut using a microtome Leica RM 2145 (thickness between 3 to 10 micrometers). Staining was performed with toluidine blue dye. Observations in SEM followed Castro et al. (2002).

SEM. Scanning electronic microscope (SEM) preparations were obtained at the "Centro de Microscopia Eletrônica" of the Universidade Federal do Rio Grande do Sul (UFRGS). SEM images were obtained from specimens fixed in formalin and preserved in alcohol. Tissues analyzed under SEM were dehydrated in 70\%, 80\%, 90\% and absolute alcohol, and critical-point-dried. Samples were adhered to carbon tape on stubs and sputter-coated with carbon and gold.

\section{RESULTS}

Genital and anal papillae in males. The morphology of the genital papilla varies throughout development and during copulation and spawning (Fig. 1). The genital papilla in juvenile males projects downward and has a flattened posterior region. In smaller specimens, the anus opens at the distal end of an elongate tubular anal papilla, which covers the urogenital opening in ventral view (Fig. 1A). In larger juveniles, a developing pre-anal organ is present (Figs. 1B-C).

The genital papilla of adult males is greatly enlarged, initially forming an incomplete hood-like structure immediately posterior to the urogenital opening (Fig. 1D). The anal papilla and anus are visible. The pre-anal organ elongates posteriorly reaching the anal papilla (Fig. 1D) or projecting over the anal opening (Figs. 1E-F) in some specimens, and the genital papilla enlarges further.

In males euthanized immediately after copulation, the anal papilla is retracted and the anus is not visible, but instead completely covered laterally by projections of the body surface and anteriorly by the pre-anal organ (Fig. 1F). Histological sections indicate that the pre-anal organ is covered by a stratified epithelium underlain by dense conjunctive tissue. It has hollow internal structure, where acidophilic granules are present. The acidophilic granules may be also located in the ventral epithelium of this organ (Fig. 2).

Genital and anal papillae in females. The anal papilla in juvenile females (Fig. 


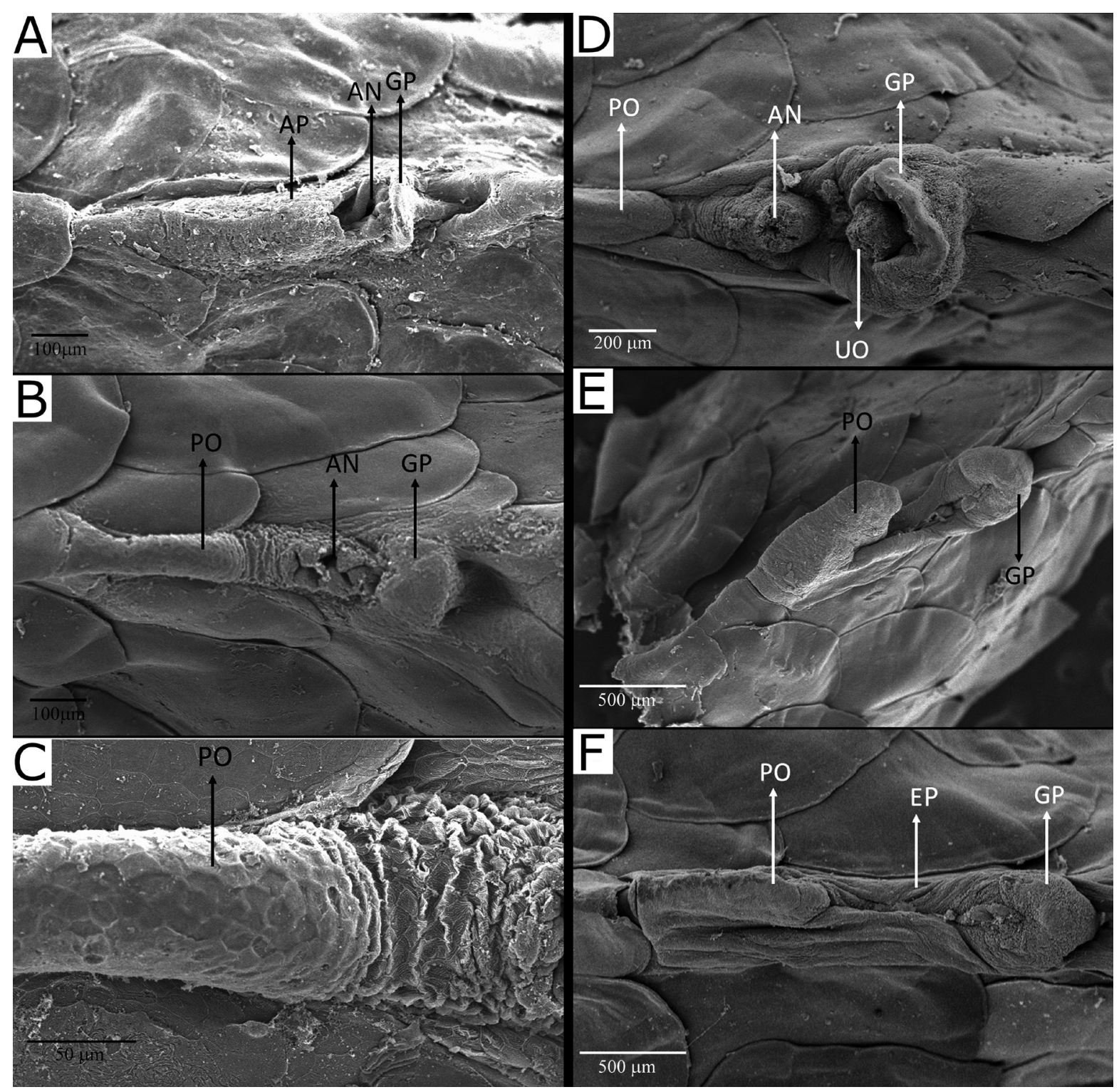

FIGURE 1 I SEM photomicrograph of the genital and anal papillae of Compsura heterura males in ventral view (anterior to left). A. Juvenile specimen measuring $15.2 \mathrm{~mm}$ SL. B. Juvenile specimen measuring $19.02 \mathrm{~mm}$ SL. C. Amplified view of the pre anal organ showed in B. D. Adult male (27.18 $\mathrm{mm} \mathrm{SL})$ showing the hood-like shape of the genital papilla. E. Adult male (28.21 $\mathrm{mm} \mathrm{SL})$ showing the hypertrophied preanal organ. F. Adult male ( $26.67 \mathrm{~mm} \mathrm{SL})$ showing genital papilla immediately after copulation showing the pre anal organ covering the anus. $\mathrm{AN}=$ anus; $\mathrm{EP}=$ epithelia lateral to the anus; $\mathrm{GP}$ = genital papilla; $\mathrm{PO}=$ pre anal organ; $\mathrm{UO}=$ urogenital opening.

3A) is larger than in juvenile males (Fig. 1B). The walls of the projecting anal papilla are highly folded with the anal opening at the distal end (Fig. 3A). The genital papilla, which also projects downward, is partially covered anteriorly by the anal papilla (Fig. 3A). The genital papilla in adult females is generally larger than the anal papilla (Fig. 3B). The urinary channel opens within the urogenital papilla, and the oviduct opens into a chamber located between the genital papilla and anal papilla (Figs. 3C-D). In females immediately following copulation, the anal and genital papillae move toward 


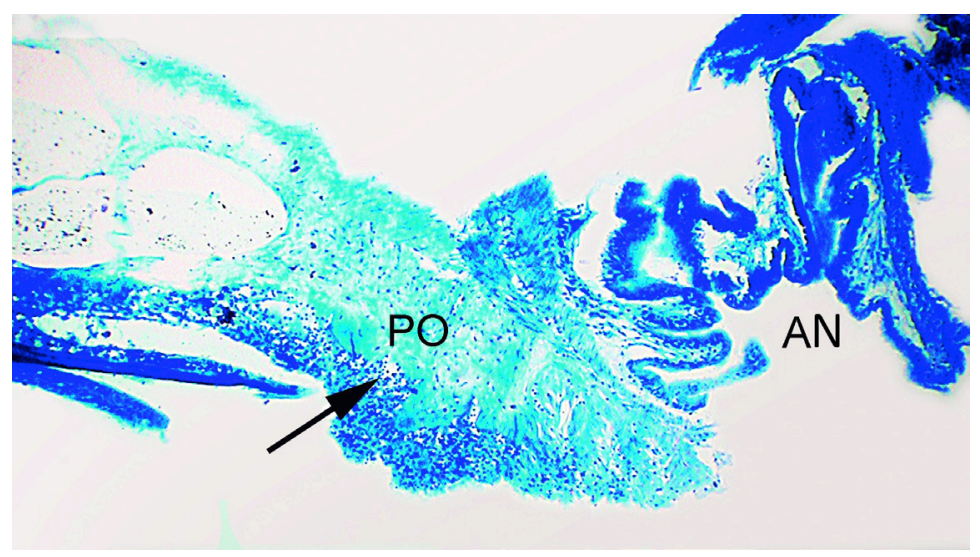

FIGURE 2 I Histological section of the adult male pre anal organ, in sagittal view, showing its acidophilic granules (26.97 mm SL; aquarium specimen). $\mathrm{AN}=$ anus; $\mathrm{PO}=$ pre anal organ; arrow = acidophilic granules.

each other, forming a closed cavity covering the genital opening (Fig. 3E). In females during spawning, the lateral edges of the genital papilla touch each other, assuming a tubular shape and covering the genital opening (Fig. 3F).

Comparative material examined. Acinocheirodon melanogramma Malabarba \& Weitzman, 1999: MCP 19238, MCP 40701. Cheirodon interruptus (Jenyns, 1842): MCP 6971. Compsura gorgonae (Evermann \& Goldsborough, 1909): MCP 16132, MCP 40302. Compsura heterura: MCP 17093, UFRGS 17001, UFRGS 17050, UFRGS 17322. Kolpotocheirodon figueiredoi Malabarba, Lima \& Weitzman, 2004: MZUSP 55219. Kolpotocheirodon theloura Malabarba \& Weitzman, 2000: MCP 11161. Macropsobrycon uruguayanae Eigenmann, 1915: UFRGS 617, UFRGS 880, UFRGS 2239, UFRGS 2277, UFR GS 2298, UFRGS 2311, UFRGS 2318, UFRGS 2329, UFRGS 6779, UFRGS 7039, UFRGS 7473, UFRGS 8791, UFRGS 8792, UFRGS 10599. Odontostilbe dialeptura (Fink \& Weitzman, 1974): MCP 11992. Odontostilbe mitoptera (Fink \& Weitzman, 1974): MCP 14713. Odontostilbe pequira (Steindachner, 1882): MCP 33240. Saccoderma hastata (Eigenmann, 1913): ICNMHN 6478. Saccoderma melanostigma Schultz, 1944: FMNH 85280. Serrapinnus calliurus (Boulenger, 1900): UFRGS 5523, UFRGS 5239, UFRGS 9368.

\section{DISCUSSION}

The possible participation of the genital papilla in insemination within Compsurini was already suggested in Malabarba (1998). However, the results of the present study show significant interaction between the genital and anal papillae in both males and females.

Female adaptations for insemination. In the female, before copulation, the anal papilla probably has the function of protecting the genital opening, covering it in ventral view. During copulation, the anal papilla changes its morphology and interacts 


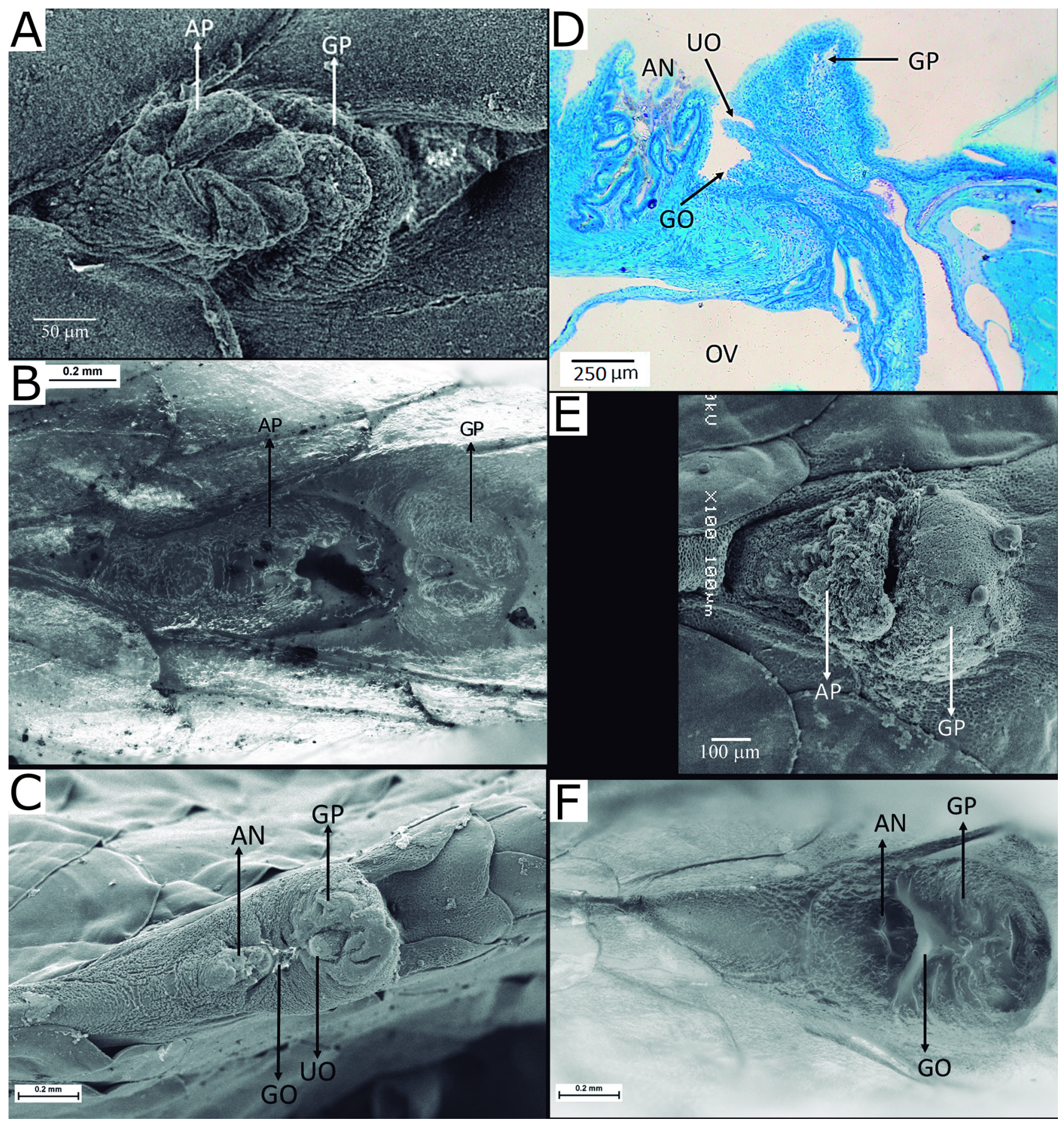

FIGURE 3 I SEM photomicrographs (A, C, E) and photos under stereomicroscope $(\mathbf{B}, \mathbf{F})$ of the genital and anal papillae in ventral view (anterior to left), and (D) histology of the genital and anal papillae of Compsura heterura females. A. Juvenile female measuring $17.6 \mathrm{~mm}$ SL. B. Virgin adult female measuring $26.56 \mathrm{~mm}$ SL showing the hood-like genital papilla and anal papilla. C. Genital papilla of a specimen measuring $26.56 \mathrm{~mm}$ SL, in ventral view, showing the separation between the genital and urinary openings. D. Genital papilla of a specimen measuring $27.24 \mathrm{~mm}$ SL showing the separation between the genital and urinary openings. E. Genital papilla of a specimen measuring 27.02 mm SL euthanized immediately after copulation showing the anal and genital papilla close to each other, forming a closed cavity covering the genital opening. F. Genital papilla of a specimen measuring $26.87 \mathrm{~mm}$ SL euthanized during spawning. AN = anus; $\mathrm{AP}=\mathrm{anal}$ papilla; $\mathrm{GO}$ = genital opening; GP = genital papilla; $\mathrm{OV}$ = ovary; $\mathrm{UD}=$ urinary duct; $\mathrm{UO}$ = urinary opening. 
with the genital papilla, forming an intermediate chamber into which the oviduct opens. Immediately after copulation, both the anal and genital papillae maintain closure of this chamber. The function of this chamber may be to assist in sperm retention near the oviduct aperture after copulation.

In many inseminating teleost species, the sperm released by the male is clumped to some degree, often as distinct sperm packages referred to as either spermatophores or spermatozeugmata, which appear to have the function of reducing sperm loss (Ginzburg, 1968; Meisner, 2005). The apparent absence of this packaging in C. heterura suggests that sperm may not be released into the external environment but within a compartment of the female body, where they are retained. It is unlikely, however, that copulation occurs by insertion of the male genital papilla inside female reproductive tract in C. heterura. Therefore, the suggested explanation is that sperm are released near the oviduct aperture and inside the chamber formed by the anal and genital papillae, which is initially open, closing immediately after copulation to prevent sperm loss.

The presence of an independent genital opening in the female, separated from the urinary opening, was observed in the examined species of Compsurini under stereomicroscope, but is unknown in other Cheirodontinae. The separation between the genital and urinary opening is known in some other groups of teleosts but it is poorly described in scientific literature.

This characteristic is observed in some externally fertilizing representatives of the Actinopterygian Cohort Euteleostomorpha, in the Nile tilapia, Oreochromis niloticus (Linnaeus, 1758), and in the Mozambique tilapia, Oreochromis mossambicus (Peters, 1852) (Cichliformes: Cichlidae). In these species the genital papilla of the male has only one opening (urogenital pore) whereas the female has two openings, the gonopore anteriorly and the urinary pore posteriorly (Oliveira, Almada, 1995; Popma, Masser, 1999). In the Nile perch, Lates niloticus (Linnaeus, 1758) (Perciformes: Latidae), the same organization is observed (Planquette, 1975). This separation also occurs in the inseminating species Ogilbia cayorum Evermann \& Kendall, 1898 (Bythidae, Cohort Euteleostomorpha). However, in this case the female's copulatory apparatus is encased in a urogenital sheath and is protected externally by a fleshy hood, which encircles the anus, genital pore, and urinary papilla. Two lobes appear in the dermal ridge of ripe females which probably serve as copulatory guides (Suarez, 1975).

In the Cohort Otomorpha, there are also examples of separation between the genital and urinary openings. It occurs both in males and females of Sardinella longiceps Valenciennes, 1847 (Clupeiformes: Clupeidae). In this species the anus, genital pore, urinary pore as well as the posterior opening of the gas bladder to the exterior are situated in a common subcutaneous pit which may be termed the "cloaca". In the male the vas deferens from each testis passes backwards and joins the other to form a common duct which opens on a muscular pear-shaped papilla immediately behind the anal opening. The urinary pore is also situated on this papilla at its distal end. The urinary duct appears to be independent of the genital duct. In the female the gonoducts unite distally and the common duct passes into a membranous papilla situated behind the anus and this papilla communicates with the cloaca near the genital opening (George, 1959). Within Otophysi, separation between the genital and urinary opening is present in Chanos chanos (Fabricius, 1775) (Gonorynchiformes: Chanidae). In this species the female has a genital pore behind the anus, and a urinary pore behind the genital pore, at the tip of 
the urogenital papilla (Chaudhuri et al., 1977).

In inseminating Otomorpha, the separation of the urinary and genital openings has also been reported in some species within Otophysi. According to Javonillo et al. (2007), in both sexes of the species Brittanichthys axelrodi Géry, 1965 (Characidae), the gonopore opens posterior to the anus, with the urinary pore having a separate opening posterior to the gonopore. Bands of skeletal muscle are present in the area of the male gonopore. The authors consider that these morphological features are likely linked to its reproductive mode of insemination. Separation of the urinary and genital openings is also present in the female of the inseminating species of the catfish genus Astroblepus Humboldt, 1805 (Astroblepidae), in which the urinary duct opens at the end of a urinary papilla and the gonoduct opens anteriorly to the urinary papilla (Spadella et al., 2012).

When analyzed at a high taxonomic level, there appears to be no solid support linking the separation of the urinary and genital openings to insemination, since this characteristic is also present in non-inseminating species, as observed in Cichlidae, Latidae, Clupeidae or Chanidae. On the other hand, there seems to be no consistent evidence that this separation is related to the type of oviposition either, which is significantly diverse among these groups. However, morphological adaptations do not always follow the same pattern in phylogenetically distant groups and, therefore, each case should be analyzed within its evolutionary and ecological context.

One possible function of this separation in inseminating $C$. heterura could be to facilitate sperm movement towards the lumen of the female reproductive tract, without interference of urine flow in the opposite direction. A second, and not exclusive hypothesis, is that a separate genital opening allows the formation of a chamber near the gonopore (discussed above) that facilitates copulation and sperm capture in this species. A third hypothesis could be to allow a larger genital opening, allowing inseminating species to lay larger eggs than using a common urogenital opening of smaller diameter. According to Azevedo et al. (2010), the inseminating species Macropsobrycon uruguayanae lay eggs up to $1.014 \mathrm{~mm}$ in diameter. These are relatively large when compared with externally fertilized species of Cheirodontinae, such as Serrapinnus heterodon (up to 0.793 mm; Gonçalves et al., 2011), Cheirodon interruptus (up to 0.700 mm; Ferriz et al., 2011) and Odontostilbe pequira (average of $0.460 \mathrm{~mm}$; Tondato et al., 2013).

The change of the female genital papilla into a tubular structure, covering the genital opening, appears to be associated with spawning, since this was only observed in females during this phase. Observations on aquarium specimens show that spawning occurs by pressing of the genital opening against a substrate, such as leaf, and leaving the egg adhered to it. We hypothesize that this morphology may support the egg during oviposition until it adheres to the substrate.

Male adaptations for insemination. In males of $C$. heterura, the region anterior to the anal papilla becomes prominent in the juvenile and forms a developed pre-anal organ in adult males. Some morphological specializations that assist in insemination have been reported in the literature. An example is the modification of the anal fin in Poeciliidae, which possesses a thickened integument in the anterior margin of the third radius and contains mucus-secreting cells, forming a structure called the "gonopodial hood" or "like prepuce hood" (Meisner, 2005). However, the formation of a pre-anal organ, which interacts with the female genital papilla as observed in C. heterura, has 
apparently not been described in any inseminating fish.

The pre-anal organ, present in the male, appears to have a secretory function due to presence of acidophilic granules that accumulate on the inside and can reach the external environment in its ventral portion. The nature of this substance remains unknown. Secretory structures are present in many groups of inseminating teleosts such as Stevardiinae, where the mature male has glandular tissue associated with modified scales on the caudal fin. This structure is formed by rays, scales, associated muscles and glandular tissue and is hypothesized to be a pheromone pumping mechanism (Weitzman, Menezes, 1998). The caudal glands are derived from club cells in Glandulocaudini and mucous cells in other tribes of Stevardiinae (Weitzman et al., 2005; Menezes, Weitzman, 2009). A similar glandular tissue is found within Compsurini, in the male caudal fin, and may have a secretory function as well (Malabarba, 1998; Malabarba, Weitzman, 1999).

The function of the pre-anal organ in C. heterura still needs more detailed studies, but its association with reproduction can be observed in males euthanized and fixed immediately after copulation. In these specimens, the anus is covered anteriorly by the pre-anal organ and laterally by projections of the body surface. The function of covering the anus remains unknown, but it is observed only during copulation, suggesting that it plays a role in reproduction, possibly increasing the surface to release pheromones or other secretions that may assist in copulation (e.g., sperm agglutination). Additional studies could test if the secretions of the pre-anal organ of the male, cited above, facilitate the adherence of sperm within the female chamber.

It can be concluded from this study that the morphological changes of the genital papillae of C. heterura are highly complex and are not only correlated with the stages of development but also with spawning and reproduction. There are also interactions of the genital papilla with the anal papilla in females and with the pre-anal organ in males that have not been previously described in the scientific literature. Finally, it is important to emphasize that this study brings additional questions regarding the role of the anal and genital papillae during copulation and spawning. These issues should be answered with further studies, not only related to the morphology of these structures but also to the behavioral biology of the species.

\section{ACKNOWLEGMENTS}

We thank Aléssio Datovo (MZUSP), Carlos Lucena (MCP), Caleb McMahan, Kevin Swagel and Susan Mochel (FMNH) for the loan of specimens, and to John R. Burns for comments on the manuscript. LRM is supported by CNPq (Proc. 307890/2016-3 and 401204/2016-2). 


\section{REFERENCES}

- Azevedo MA, Malabarba LR, Burns JR. Reproductive biology and development of Gill glands in the inseminating characid, Macropsobrycon uruguayanae Eigenmann, 1915 (Cheirodontinae: Compsurini). Neotrop Ichthyol. 2010; 8(1):87-96. http://dx.doi.org/10.1590/S167962252010005000004

- Bertaco VA, Malabarba LR. A new species of the characid genus Hollandichthys Eigenmann from coastal rivers of southern Brazil (Teleostei: Characiformes) with a discussion on the diagnosis of the genus. Neotrop Ichthyol. 2013; 11(4):767-78. http://dx.doi.org/10.1590/S167962252013000400004

- Burns JR, Weitzman SH. Intromittent organ in the genus Monotocheirodon (Characiformes: Characidae). Copeia. 2006; 2006(3):529-34. https://doi. org/10.1643/0045-8511(2006)2006[529:IOIT $\mathrm{GM}] 2.0 . \mathrm{CO} ; 2$

- Burns JR, Weitzman SH, Malabarba LR. Insemination in eight species of Cheirodontine fishes (Teleostei: Characidae: Cheirodontinae). Copeia. 1997; 1997(2):433-38. http://dx.doi.org/ doi:10.2307/1447767

- Castro DC, Romero MD, Dreon M. Ultrastructure of Proechinophthirus zumpti (Anoplura, Echinophthiriidae) by scanning electron microscopy. Mem Inst Oswaldo Cruz. 2002; 97(6):813-18. https://doi. org/10.1590/S0074-02762002000600011

- Chaudhuri H, Juario J, Samson R, Mateo R. Notes on the external sex characters of Chanos chanos Forskal spawners. SEAFDEC. 1977; 1(2):17-20.

- Ferriz RA, Bentos CA, Fernández EM, López GR. Reproducción y dinámica poblacional de Cheirodon interruptus (Ostariophysi: Characidae) en el arroyo El Portugués, alta cuenca del río Samborombón, Argentina. Lat Am J Aquat Res. 2011; 39(1):151-60.

- Fukakusa CK, Mazzoni TS, Malabarba LR. Zygoparity in Characidae - the first case of internal fertilization in the teleost cohort Otomorpha. Neotrop ichthyol. 2020; 18(1):e190042. https://doi. org/10.1590/1982-0224-2019-0042
- Garber JC, Barbee RW, Bielitzki JT, Clayton LA, Donovan JC, Kohn DF et al. Guide for the care and use of laboratory animals. Washington DC: The National Academies Press; 2011.

- George KC. A method for distinguishing the sex of the oil-sardine, Sardinella longiceps Val. in the field. Indian J Fish. 1959; 6(2):322-26. Available from: http:// eprints.cmfri.org.in/id/eprint/1885

- Gerrits PO, Horobin RW. The application of glycol methacrylate in histotechnology; some fundamental principles. Groninga: Faculteit der Geneeskunde; 1991.

- Ginzburg AS. Fertilization in Fishes and the problem of Polyspermy. Moscow: Moscow Academy of Science; 1968.

- Gonçalves CS, Souza UP, Braga FMS. Population structure, feeding and reproductive aspects of Serrapinnus heterodon (Characidae, Cheirodontinae) in a Mogi Guaçu reservoir (SP), upper Paraná River basin. Acta Limno Bras. 2011; 23(1):13-22. https://doi.org/10.4322/ actalb.2011.014

- Javonillo R, Burns JR, Weitzman SH. Reproductive morphology of Brittanichthys axelrodi (Teleostei: Characidae), a miniature inseminating fish from South America. J Morphol. 2007; 268(1):23-32. https://doi.org/10.1002/jmor.10500

- Javonillo R, Burns JR, Weitzman SH. Sperm modifications related to insemination, with examples from the Ostariophysi. In: Jamieson BGM, editor. Reproductive biology and phylogeny of fishes. Enfield: Science Publishers; 2009. p.723-63.

- Jerep FC. Revisão taxonômica e filogenia da tribo Compsurini (Characiformes: Characidae: Cheirodontinae). [PhD Thesis]. Porto Alegre: Pontifícia Universidade Católica do Rio Grande do Sul; 2011. Available from: http://repositorio.pucrs.br/ dspace/bitstream/10923/5386/1/000431486Texto\%2BCompleto-0.pdf

- Karnovsky MJ. A formaldehydeglutaraldehyde fixative in high osmolality for use in electron microscopy. J Cell Biol. 1965. 27(2):137A-38A. 
- Kutaygil DL. Insemination, sexual differentiation and secondary sex characters in Stevardia albipinnis Gill. Hydrobiol Univ Istanbul Fen Fak Mecm Sér B. 1959; 24:93-128.

- Malabarba LR. Monophyly of the Cheirodontinae, characters and major clades (Ostariophysi: Characidae). In: Malabarba LR, Reis RE, Vari RP, Lucena ZMS, Lucena CAS, editors. Phylogeny and Classification of Neotropical Fishes. Porto Alegre: Edipucrs; 1998. p.193-233.

- Malabarba LR, Weitzman SH. A new genus and species of South American fishes (Teleostei: Characidae: Cheirodontinae) with a derived caudal fin, including comments about inseminating cheirodontines. Proc Biol Soc Washington. 1999; 112(2):410-32.

- Meisner AD. Male modifications associated with insemination in teleosts. In: Grier HJ, Uribe MC, editors. Viviparous Fishes. Homestead: New Life Publications; 2005. p.165-90.

- Menezes NA, Ferreira KM, NettoFerreira AL. A new genus and species of inseminating characid fish from the rio Xingu basin (Characiformes: Characidae). Zootaxa. 2009; 2167(1):47-58. https://doi. org/10.11646/zootaxa.2167.1.3

- Menezes NA, Weitzman SH. Systematics of the Neotropical fish subfamily Glandulocaudinae (Teleostei: Characiformes: Characidae). Neotrop Ichthyol. 2009; 7(3):295-370. https://doi. org/10.1590/S1679-62252009000300002

- Munehara H, Takano K, Koya Y. Internal gametic association and external fertilization in the elkhorn sculpin, Alcichthys alcicornis. Copeia. 1989; 1989(3):673-78. http://dx.doi.org/ doi:10.2307/1445494

- Oliveira RF, Almada VC. Sexual dimorphism and allometry of external morphology in Oreochromis mossambicus. J Fish Biol. 1995; 46(6):1055-64. https://doi. org/10.1111/j.1095-8649.1995.tb01409.x

- Pecio A, Burns JR, Weitzman SH. Comparison of spermiogenesis in the externally fertilizing Hemigrammus erythrozonus and the inseminating Corynopoma riisei (Teleostei: Characiformes: Characidae). Neotrop Ichthyol. 2007; 5(4):457-70. http://dx.doi. org/10.1590/S1679-62252007000400005
- Planquette P. Dimorphisme sexuel chez Lates niloticus (poisson Centropomidae). Cah ORSTOM (Sci Hum). 1975; 9(1):9-12.

- Popma T, Masser M. Tilapia: Life History and Biology. Stoneville: SRAC Publication; 1999.

- Sabaj MH. Standard symbolic codes for institutional resource collections in herpetology and ichthyology: An Online Reference [Internet] Version 7.1. Washington, D.C: American Society of Ichthyologists and Herpetologists; 2019. Available from: https://asih.org/standardsymbolic-codes

- Spadella MA, Oliveira C, Ortega H, Quagio-Grassiotto I, Burns JR. Male and female reproductive morphology in the inseminating genus Astroblepus (Ostariophysi: Siluriformes: Astroblepidae). Zool Anz. 2012; 251(1):3848. http://dx.doi.org/doi:10.1016/j. jcz.2011.05.005

- Suarez SS. The Reproductive Biology of Ogilbia cayorum, a Viviparous Brotulid Fish. Bull Mar Sci. 1975; 25(2):143-73.

- Tondato KK, Fialho CB, Súarez YR. Reproductive ecology of Odontostilbe pequira (Steindachner, 1882) (Characidae, Cheirodontinae) in the Paraguay River, southern Pantanal, Brazil. Environ Biol Fish. 2013; 97:13-25. https://doi. org/10.1007/s10641-013-0119-5

- Weitzman SH, Menezes NA. Relationships of the tribes and genera of the Glandulocaudinae (Ostariophysi: Characiformes: Characidae) with a description of a new genus, Chrysobrycon. In: Malabarba LR, Reis RE, Vari RP, Lucena ZMS, Lucena CAS, editors. Phylogeny and Classification of Neotropical Fishes. Porto Alegre: Edipucrs; 1998. p.171-92.

- Weitzman SH, Menezes NA, Evers H-G, Burns JR. Putative relationships among inseminating and externally fertilizing characids, with a description of a new genus and species of Brazilian inseminating fish bearing an anal-fin gland in males (Characiformes: Characidae). Neotrop Ichthyol. 2005; 3(3):329-60. http://dx.doi.org/doi:10.1590/S167962252005000300002 


\section{AUTHOR'S CONTRIBUTION @}

Antônio Queiroz Lezama: Conceptualization, Data curation, Formal analysis, Investigation, Methodology, Writing-original draft, Writing-review and editing.

Luiz R. Malabarba: Data curation, Formal analysis, Funding acquisition, Methodology, Supervision,

Writing-review and editing.

\section{Neotropical Ichthyology}

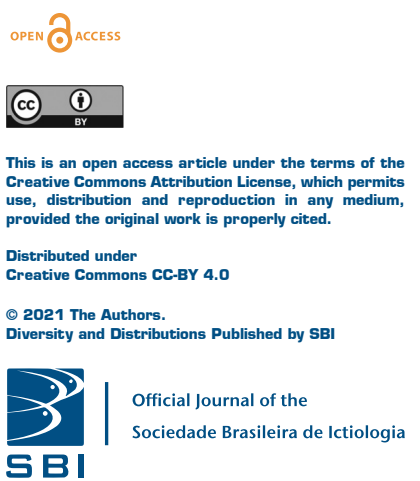

\section{ETHICAL STATEMENT}

This study conforms to the principles outlined in the Guide for the care and use of laboratory animals (Garber et al., 2011) and was approved by the Ethics Committee on Animal Use of the UFRGS.

\section{COMPETING INTERESTS}

The authors declare no competing interests.

\section{HOW TO CITE THIS ARTICLE}

- Lezama AQ, Malabarba LR. The genital and anal papillae of Compsura heterura (Characidae:

Cheirodontinae): morphological structure and possible role in insemination. Neotrop Ichthyol. 2021;

19(1):e200079. https://doi.org/10.1590/1982-0224-2020-0079 